\title{
REVISION OF THE MORPHOLOGY AND SYSTEMATIC POSITION OF THE GENUS ACANTHAMBONIA (BRACHIOPODA, INARTICULATA)
}

The systematic position of the inarticulate brachiopod genus Acanthambonia has long been uncertain; it has usually been assigned to the order Lingulida within the subfamily Acanthamboniinae (Cooper, 1956; Wright, 1963; Rowell, 1965). V. Gorjansky (Горянский, 1969) was the first to note the marked similarities of Acanthambonia with the siphonotretid genus Helmersenia. The following features of Acanthambonia have been used to associate it with the lingulids: similar structure of pseudointerareas, lack of a pedicle foramen and an inner pedicle tube on the ventral valve. Recently, the similarity of this genus to Helmersenia and the presence of long hollow spines on the shell surface lead V. Havliček to include it within the family Siphonotretidae (Havliček, 1982).

An unequivocal definition of the systematic position of Acanthambonia has been hampered mainly by a scarcity of specimens. Recently, in the East Baltic area, only rare specimens from more than 20 borehole cores have been recorded from beds of approximately the same age, from Vormsi Stage: Jakšai (Central Lithuania) - 1 ventral and 1 dorsal valves; Elva (South Estonia) - fragments, and from the lowermost Pirgu Stage: Moe (North Estonia) - 1 fragment; Võhma (Central Estonia) - 2 valves (Горянский, 1969). Therefore of particular importance is a fauna of microscopic inarticulate brachiopods, mostly acrotretids and lingulids from the transitional beds between the Upper Ordovician Vormsi and Pirgu Stages of Estonia (approximately the boundary beds of $D$. linearis/D. complanatus zones) in the Viljandi core at a depth interval of $307.5-312.5 \mathrm{~m}$. In this collection Acanthambonia portranensis Wright is present as more than 100 well-preserved ventral and dorsal valves. Etching of this material was carried out using dilute acetic acid. The results were obtained through the study of these shells by the scanning electron microscope (SEM) at the Institute of Geology, ESSR Academy of Sciences in Tallinn.

Significantly, the discovery of a pedicle foramen and inner pedicle tube on the valve that was previously considered to be dorsal, has important consequences for the classification of the Acanthamboninae. A circular foramen of diameter $20-40 \mu \mathrm{m}$ is situated in the apical part of this valve immediately in front of the pseudointerarea (Plate I, Fig. 2). A narrow pedicle tube is developed from the foramen inwardly and anteriorly (Plate I, Figs 2,3; the Figure) and is attached to the valve floor. The inner foraminal opening is semielliptical and is situated at a considerable distance from the umbo. Both the inner and outer foramens are open throughout all stages of ontogeny in the specimens studied. Thus, the ventral pseudointerarea is relatively high, flat, compact and almost horizontal and is distinctly isolated from the other parts of the shell. In the apical portion of the pseudointerarea there is often a scar recording changes in the growth direction of the ventral pseudointerarea during early stages of ontogeny (Plate I, Fig. 1). On this basis the ventral pseudointerarea of Acanthambonia can be compared only with that of the 

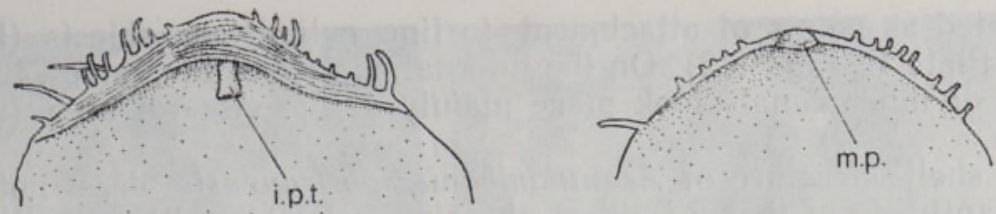

Ventral pseudointerarea with internal pedicle tube (i. p.t.) and dorsal reduced pseudointerarea with median plate (m. p.) of Acanthambonia portranensis Wright.

genus Mirilingula, in which the development of the pseudointerarea has been studied throughout ontogeny (Конева, Попов, 1983). Among the siphonotretids the ventral pseudointerareas of the genera Dysoristus and Helmersenia resemble that described above. They are isolated from the rest of the shell and have the shape of a flat, undivided sheet. On the basis of these comparisons it is reasonable to consider the inner pedicle tube of Acanthambonia as equivalent to the same structures in members of the family Lingulellotretidae and thus, by homology it may be taken to represent a fine pedicle tube.

Nevertheless, it is important to note the essential structural differences between the ventral pseudointerareas of Acanthambonia and those of the superfamily Acrotretacea (order Acrotretida). There is a triangular delthyrium on the early postlarval shells of some Early Palaeozoic acrotretids of the subfamilies Linnarssoniinae and Scaphelasmatinae (Пельман, 1977; Попов, 1975; Назаров, Попов, 1980; Rowell, 1980). In both, the foramen was developed as a result of convergence of the posterior delthyrial margins. This is true of also the Early Cambrian genus Hadrotreta (subfamily Acrotretinae). Consequently, only a small part of the ventral valve around the foramen and in the central portion of its posterior margin are strictly equivalent to the ventral pseudointerarea of the order Lingulida. Ventral propáreas of acrotretaceans, however, correspond to the posterolateral portions of the ventral valve of lingulids. Such changes in growth are also reflected in the topography of the muscle attachment areas on the ventral valve; cardinal muscle impressions which serve as possible equivalents of the posterolateral ventral muscle fields of the Obolacea, have migrated to the posterior valve slope of the acrotretids. In siphonotretids such changes in the distribution of the main ventral muscle marks have not been observed.

The shell of Acanthambonia is not differentiated into primary and secondary layers. Instead it is composed of two or three parallel apatite lamellae of about $5 \mu \mathrm{m}$ thickness. The surfaces of the lamellae are wavy (Plate I, Fig. 4) and in places are united or separated by strips of variable thickness (the greatest observed distance between lamellae is about $3 \mu \mathrm{m}$ ). Growth marks in the form of concentric lamellae do not noticeably disturb the structure of the external mineral lamella (Plate I, Fig. 4). In some cases, after the formation of a growth lamella the mineral lamella continued to grow at some distance from its margin. In this way a hollow developed between the inner surface of the growth lamella and the outer shell surface to a thickness of up to $0.8 \mu \mathrm{m}$, which may coincide with the greatest possible thickness of periostracum. The walls of the hollow spines set at the proximal ends are quite inseparable from the external shell surface judging by their thickness and structure. The diameter of canals in the proximal part of the spines is $4.5-5 \mu \mathrm{m}$. The spines evidently grew soon after attachment and shortly after apatite deposition commenced. The smallest specimens studied have a shell diameter of about $250 \mu \mathrm{m}$ and have one or two rows of spines along the peripheral part, whereas in the posterolateral portions of valves there are hook-like curved spines, 
interpreted as points of attachment to fine cylindrical objects (Plate I, Fig. 1; Plate II, Figs 1,3). On the internal surface of the valves, the overgrowth of inner canals took place mainly at the visceral area (Plate I, Fig. 1).

The shell structure of Acanthambonia portranensis does not differ significantly from that of either the siphonotretids (Biernat, Williams, 1971 ) or the lingulids, although it consists of fewer mineral lamellae. But it differs considerably from the shell structure of Early Paleozoic Acrotretacea, in which the primary layer is formed of hollow prisms subparallel to the shell surface. The secondary layer is composed of apatite lamellae connected by cylindrical bars (Poulsen, 1971).

The presence of the foramen on the inner pedicle tube and the occurrence of hollow spines on the valve surfaces indicate that the subfamily Acanthamboniinae undoubtedly belongs to the siphonotretids, where Helmersenia is also placed more appropriately.

The latter is characterized by a small outer foramen, a lack of differentiated spines and also by a similar structure of the ventral pseudointerarea. Nevertheless, it should be noted that Acanthambonia and other siphonotretids differ from members of the order Acrotretida, where they are usually included, in details of the surface ornamentation, and in the construction of the foramen and the pseudointerarea of the ventral valve. However, in the siphonotretids the position of the posterolateral ventral muscle fields has not changed, whilst the differentiation of the valve into the primary and secondary layers is lacking. Siphonotretids also lack bars between the mineral lamellae. In contrast, the shell microstructure of siphonotretids gives evidence of their closer relationship with lingulids, particularly the peculiar family Lingulellotretidae. In all these forms the foramen and inner pedicle tube have grown out of the pedicle groove (Конева, Попов, 1983).

Significantly, the evidence presented above strongly supports V. Gorjansky (Горянский, 1969), who has argued, that the siphonotretids represent an independent group.

Order Siphonotretida Gorjansky, 1960

Family Siphonotretidae Kutorga, 1848

Subfamily Acanthamboniinae Cooper, 1956

Acanthamboniinae: Cooper, 1956, p. 211; Rowell, 1965, p. H 269.

Diagnosis. Shell biconvex, externally covered with undifferentiated hollow spines. Ventral valve with flattened pseudointerarea significantly isolated from lateral portions of the shell. Outer foramen small, apical, continuous with inner pedicle tube, sometimes attached to floor of the valve. Pseudointerarea of the dorsal valve low, straight, with well developed concave median plate.

Remarks. Apart from Acanthambonia we include the genus Helmersenia in this subfamily. The problem of whether the genus Quasithambonia (Bednarczyk, Biernat, 1978) belongs to this subfamily or not, cannot be

\section{PLATE I}

Figs 1-4. Acanthambonia portranensis Wright, 1963.

$1 a$ - dorsal valve $\mathrm{Br} 1665, \times 65 ; 1 b$ - the same specimen, viewed from the posterior margin, $\times 85$, depth $310.9 \mathrm{~m} ; 2$ - ventral valve $\mathrm{Br} 1666$, foramen, $\times 465$, depth $310.9 \mathrm{~m}$; 3 - ventral valve $\mathrm{Br} 1667$, inner pedicle tube: $3 a-\times 330 ; 3 b-\times 190$, depth $311.6 \mathrm{~m}$; $4 a-\mathrm{Br} 1668$, longitudinal section of the spine and growth lamella (g. 1.), $\times 1550$; $4 b$ - the same specimen, cross-section of the peripheral part of the valve, $\times 750$; depth $310.9 \mathrm{~m}$. Viljandi core, Upper Ordovician, the transitional beds of the Vormsi and Pirgu Stages. 

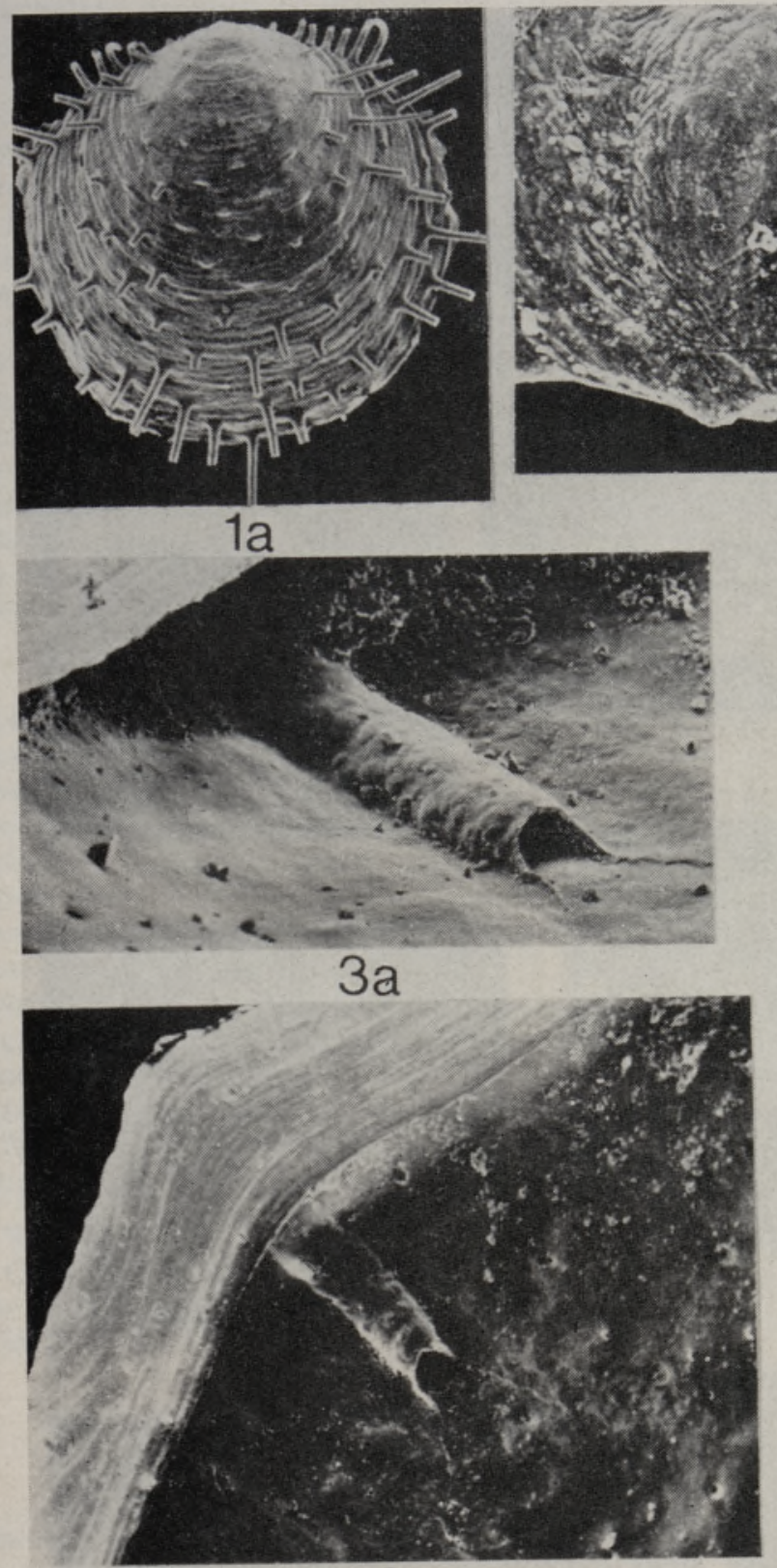

$3 b$

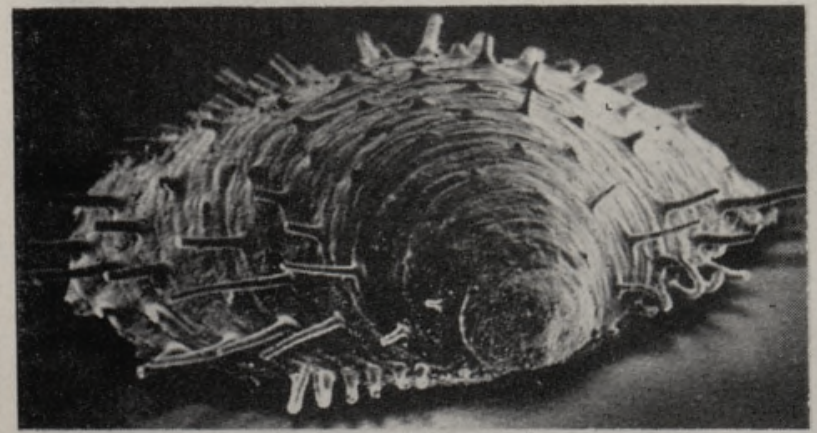

1b
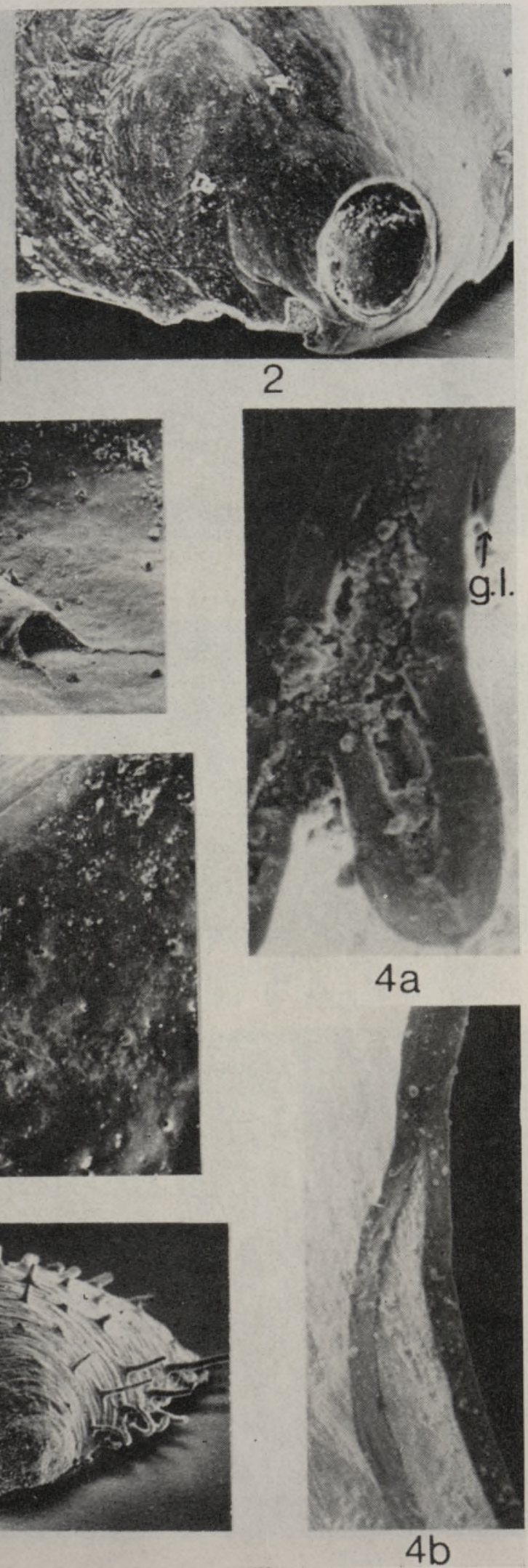

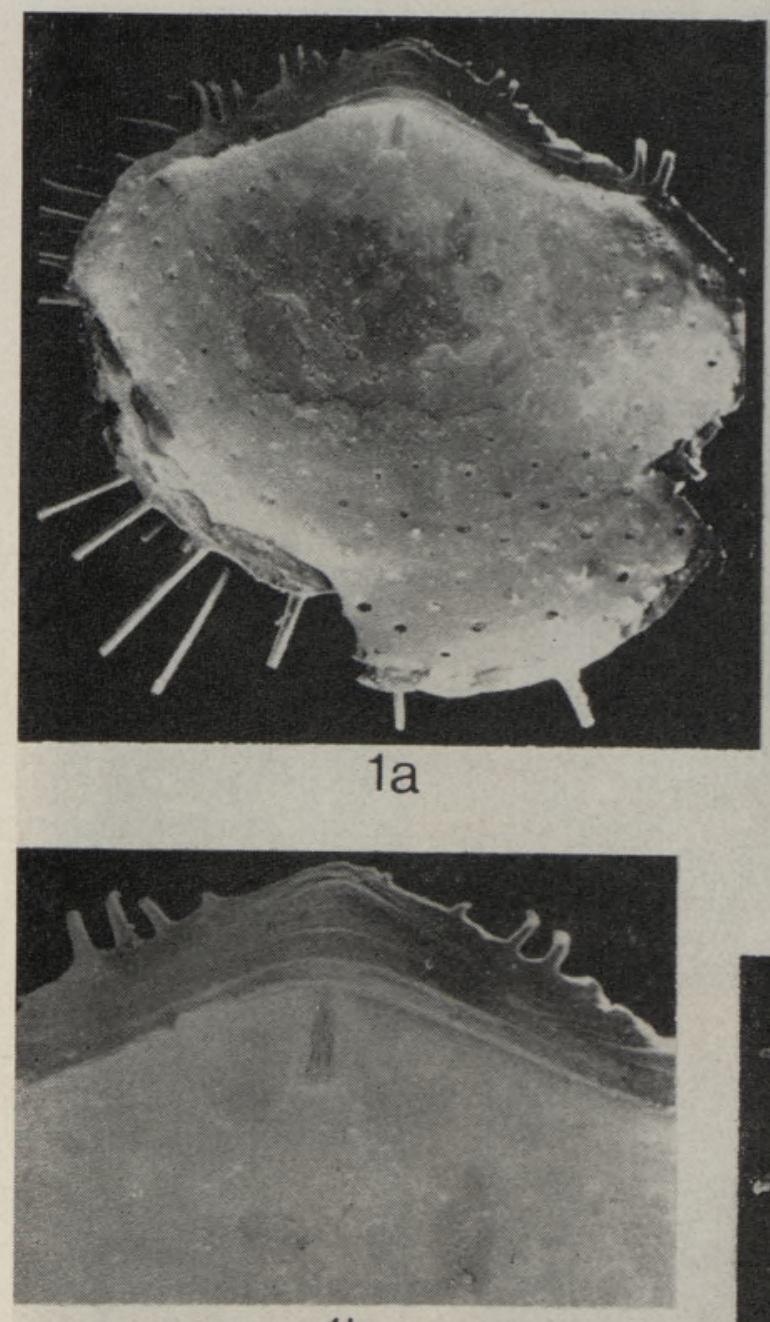

$1 b$
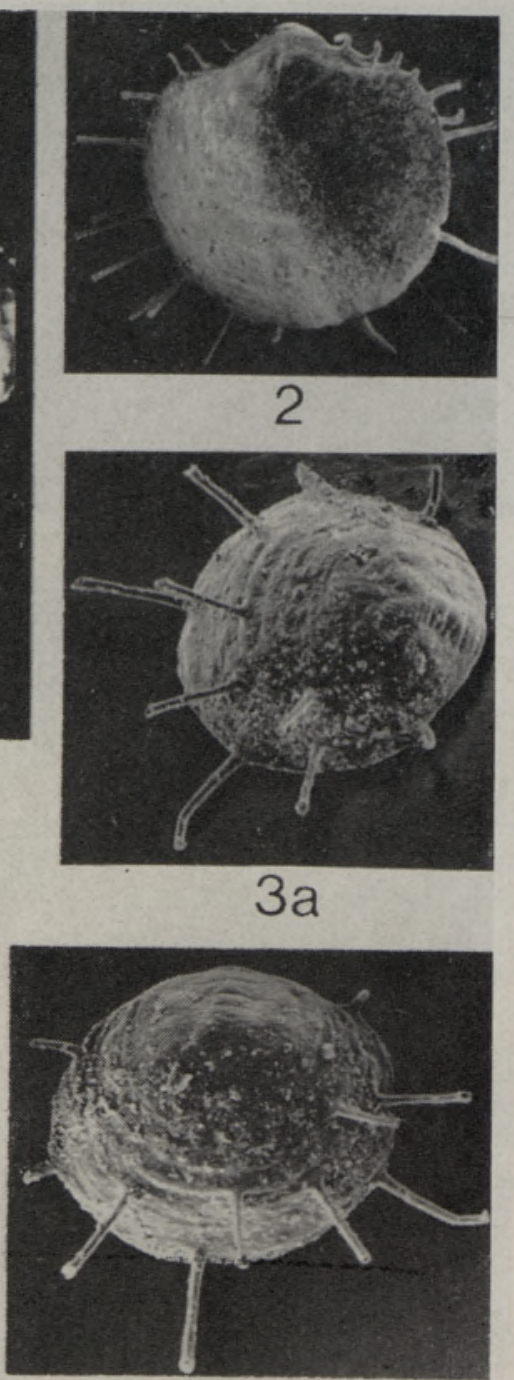

$3 b$

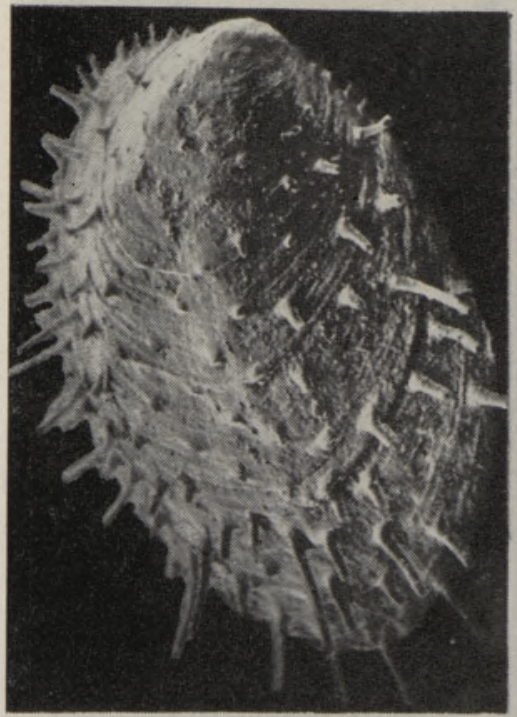

$4 a$

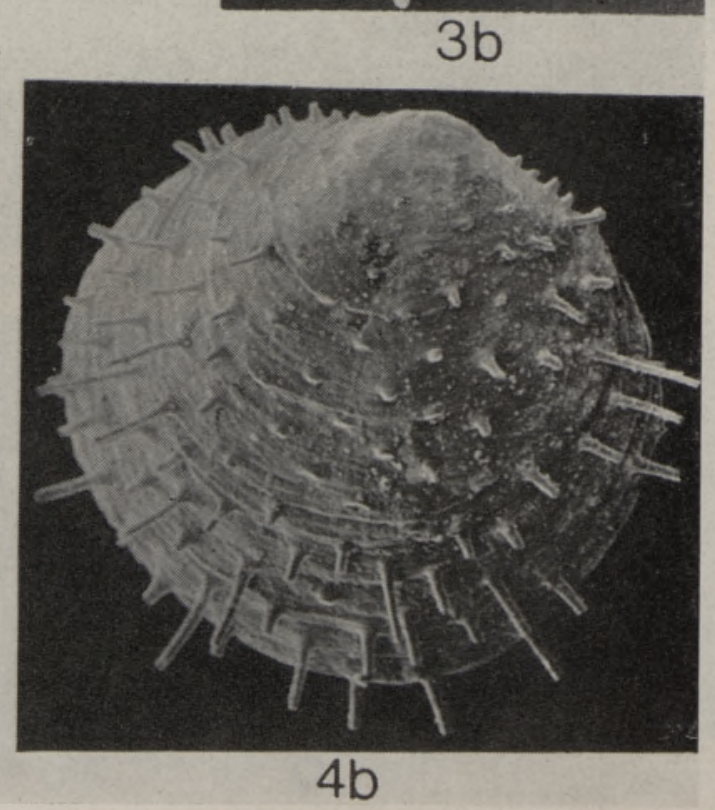


determined because of the lack of data on the structure of ventral pseudointerareas and apical portions of both valves.

Genus Acanthambonia Cooper, 1956

Acanthambonia: Cooper, 1956, p. 211; Rowell, 1965, p. Н 269; Горянский, 1969, p. 49.

Diagnosis. Acanthamboniinae with a high, flat pseudointerarea located on the ventral valve. Inner pedicle tube long, flattened, attached to the valve floor.

Comparison. This genus is most similar to Helmersenia but differs in having a relatively high ventral pseudointerarea and a flat, long inner pedicle tube, which was functional throughout ontogeny.

Remarks. The presence of the inner pedicle tube on the ventral valve of Acanthambonia (previously considered to be a dorsal valve) is not merely characteristic of Acanthambonia portranensis Wright. For example, a short median ridge, described only on casts of species A. klabovensis Havliček (1982), may indicate the presence of an inner pedicle tube. A pedicle tube and its inner opening are also seen in a specimen A. minutissima Cooper (1956, Plate 18, Fig. 25).

\section{Acanthambonia portranensis Wright, 1963}

Plates I, II

Acanthambonia portranensis: Wright, 1963, p. 231, Plate I, Figs 29-31; Горянский, 1969, p. 49, Plate 6, Figs 7, 8.

Remarks. The ventral valve, which was earlier considered to be dorsal, (see synonymy), has a high, somewhat flattened, orthocline pseudointerarea; apical foramen small and dorso-ventrally flattened. Inner pedicle tube with crack-like inner foramen attached to the valve floor. Dorsal valve has a small sinus and a low anacline pseudointerarea with a small concave median plate.

Distribution. Upper Ordovician, the transitional beds of the Vormsi and Pirgu Stages of Estonia; Vormsi Stage of Lithuania; the Portrane Limestone (Cautleyan) of Ireland.

Material and locality. Viljandi core (Central Estonia), at a depth interval of $307.5-312.5 \mathrm{~m}$ : 71 ventral and 35 dorsal valves; Jakšai core (Central Lithuania), at a depth of $985.0 \mathrm{~m}$ : 1 ventral and 1 dorsal valves.

We are indebted to Drs M. Rubel, D. A. T. Harper (Galway) and M. G. Bassett (Cardiff) for the helpful criticism of this paper. It is pleasure to acknowledge A. Noor for linguistic help and E. Klimov for the SEM photography.

\section{REFERENCES}

Bednarczyk, W., Biernat, G. Inarticulate Brachiopods from the Lower Ordovician of the

Holy Cross Mountains, Poland. - Acta Palaeontol. Pol., 1978, 23, 293-316.
Biernat, G., Williams, A. Shell structure of the Siphonotretacean Brachiopoda, - Palaeontology, 1971, 14, 491-502.

PLATE II

Figs 1-4. Acanthambonia portranensis Wright, 1963.

$1 a$ - ventral valve $\mathrm{Br} 1669$, inner structure, $\times 75 ; 1 b$ - the same specimen, pseudointer. area, $\times 150$, depth $310.1 \mathrm{~m} ; 2-$ ventral valve $\mathrm{Br} 1670$, inner structure, $\times 55$, depth $310.9 \mathrm{~m} ; 3 a, b-\mathrm{Br} 1671$, dorsal valve of juvenile specimen in different positions, $\times 150$, depth $312.5 \mathrm{~m} ; 4 a$ - dorsal valve $\mathrm{Br} 1672, \times 75 ; 4 b-$ the same specimen, $\times 75$, depth $310.9 \mathrm{~m}$. Viljandi core, Upper Ordovician, the transitional beds of the Vormsi and Pirgu Stages. 
Cooper, G. A. Chazian and related Brachiopods. - Smithson. Misc. Collect., 1956, 127̄, $1-1024$.

Havliček, V. Lingulacea, Paterinacea and Siphonotretacea (Brachiopoda) in the Lower Ordovician sequence of Bohemia. - Sbor. geol, věd. Paleont., 1982, 25, 9-82.

Poulsen, $V$. Notes on an Ordovician acrotretacean Brachiopod from the Oslo Region. Bull. Geol. Soc. Den., 1971, 20, 265-278.

Rowell, A. Class Inarticulata. - In: Treatise on Invertebrate Palaeontology, Part H (Brachiopoda). Geol. Soc. Amer. and Univ. Kansas Press, 1965, H260-H296.

Rowell, A. Inarticulate Brachiopods of the Lower and Middle Cambrian Pioche Shale of the Pioche District, Nevada. - Univ. Kans. Paleontol. Contrib. Pap., 1980, N $98,1-26$.

Wright, A. D. The fauna of the Portrane limestone. 1. The Inarticulate Brachiopods. Bull. Brit. Mus. (Nat. Hist.) Geol., 1963, 8, 221-254.

Горянский В. Ю. Класс Inarticulata. - В кн.: Основы палеонтологии. Брахиоподы, мшанки. М., 1960, 172-182.

Горянский В. Ю. Беззамковые брахиоподы кембрийских и ордовикских отложений Северо-Запада Русской платформы. М., 1969.

Конева С. П., Попов Л. Е. Некоторые новые лингулиды из верхнего кембрия и нижнего ордовика Малого Каратау. - В кн.: Стратиграфия и палеонтология нижнего палеозоя Казахстана. Алма-Ата, 1983, 110-124.

Назаров Б. Б., Попов Л. Е. Стратиграфия и фауна кремнисто-карбонатных толщ ордовика Казахстана (радиолярии, беззамковые брахиоподы). - Тр. Геол. ин-та АН СССР, 1980, вып. 331.

Пельман Ю. Л. Ранне- и среднекембрийские беззамковые брахиоподы Сибирской платформы. - Тр. ИГиГ СО АН СССР, 1977, вып. 316.

Попов Л. Е. Беззамковые брахиоподы из среднего ордовика хребта Чингиз. - Палеонт. ж., 1975 , № $4,32-41$.

All-Union Geological Research Institute

Received

Academy of Sciences of the Estonian SSR,

Nov. 5,1985

Institute of Geology

L. POPOV J. JOLVAK

\section{UUSI ANDMEID PEREKONNA ACANTHAMBONIA EHITUSEST JA SUSTEMAATILISEST KUULUVUSEST (BRACHIOPODA, INARTICULATA)}

Artiklis on kirjeldatud uusi tunnuseid lukuta brahhiopoodi Acanthambonia portranensis Wright ventraalkaane ehituses ja täpsustatud alamsugukonna Acanthamboniinae perekondlikku koosseisu.

\section{Л. ПОПОВ, Я. НЫЛВАК}

\section{НОВЫЕ ДАННЫЕ О СТРОЕНИИ И СИСТЕМАТИЧЕСКОМ ПОЛОЖЕНИИ РОДА ACANTHАМВONIA (BRACHIOPODA, INARTICULATA)}

Систематическое положение рода Acanthambonia до последнего времени нельзя было считать определенным из-за немногочисленности найденных экземпляров. Поэтому особый интерес представляет комплекс микроскопических беззамковых брахиопод, включающий главным образом акротретид и лингулид, распространенный в пограничных отложениях вормсиского и пиргуского горизонтов верхнего ордовика Эстонии. При этом обнаружение у Acanthambonia portranensis форамена, внутренней ножной трубочки на створке (которая обычно принималась за спинную) и полых игл на поверхности у изученных створок свидетельствует о несомненной принадлежности подсемейства Acanthamboniinae к сифонотретидам, из которых наиболее близким родом является Helmersenia. Последний характеризуется также маленьким наружным фораменом, отсутствием дифференциации игл и сходным строением вентральной ложной ареи. В то же время, из отличнй рода Acanthambonia (и других сифонотретид от типичных представителей отряда Acrotretida), помимо поверхностной орнаментации, следует отметить и иной способ образования форамена и ложной ареи на брюшной створке. Однако у сифонотретид не наблюдается изменений в расположении заднебоковых вентральных мускульных полей, а также дифференциации раковины на первичный и вторичный слон. Нет у сифонотретид и перемычек между минеральными пластинами. Микроструктура раковины 
сифонотретид свидетельствует скорее об их более тесном родстве с лингулидами. Эти формы характеризуются наличием форамена и внутренней ножной трубочки, развивающейся из желобка для ножки. Все вышесказанное поддерживает точку зрения В. Горянского о таксономическом ранге сифонотретид в качестве самостоятельного отряда. В то же время, отнеся вслед за В. Гавличеком подсемейство Acanthamboniinae к семейству Siphonotretidae, даем дополненные диагнозы.

Отряд Siphonotretida Gorjansky, 1960

Семейство Siphonotretidae Kutorga, 1848

Подсемейство Acanthamboniinae Cooper, 1956

Acanthamboniinae: Cooper, 1956, c. 211; Rowell, 1965, c. H 269.

Диагноз. Раковина двояковыпуклая. Поверхность с полыми иглами одного порядка. На брюшной створке уплощенная ложная арея, хорошо обособленная от боковых частей раковины. Форамен маленький, апикальный. Ложная арея спинной створки низкая, прямая, с хорошо развитой вогнутой срединной пластинкой. В брюшной створке в различной степени развита иногда зарастающая внутренняя ножная трубочка.

Замечания. Помимо номинального к подсемейству относим и род Helmersenia. Bonрос об отнесении к данному подсемейству рода Quasithambonia оставим открытым из-за отєуғствия сведений о строении вентральных ложных арей и апикальных частей обеих створок:

Род Acanthambonia Cooper, 1956

Acanthambonia: Cooper, 1956, е. 211; Rowell, 1965, с. Н 269; Горянский, 1969, с. 49.

Диагноз. Acanthamboninae с высокой плоской ложной ареей на брюшной створке. Внутренняя :ножная фрубочка длинная; уплоренная, сросшаяся со дном створки.

Сравнение. Данный род отличается от наңболее, близкого Helmersenia относительно высокой ложной ареей брюшной створки и нлоской длинной внутренней ножной трубơkой, прижатой ко дну створки, - функционирующей на всех стадиях онтогенеза.

Замечания. Наличие внутренней ножной трубочки на брюшной створке Acanthambonia является характерным не только для $A$. portranensis Wright. Так, описанный только на ядрах короткий срединный валик у вида $A$. klabovensis Havliček скореe всего отпечаток внутренней ножной трубочки. Внутреннее отверстие форамена и ножная трубочка видны также и на экземпляре $A$. minutissima Cooper (1956, табл. 18, фиг. 25).

\section{Acanthambonia portranensis Wright, 1963}

Табл. I, II

Acanthambonia portranensis: Wright, 1963, с. 231, табл. 1, фиг. 29-31; Горянский, 1969, c. 49 , табл. 6 , фиг. 7,8 .

Замечания. Брюшная створка, принимавшаяся в ранних описаниях за спинную, имеет высокую, уплощенную, ортоклинную 'ложную арею, маленький апикальный форамен и сдавленную дорсо-вентрально, сросшуюся со дном створки внутреннюю ножную трубочку со щелевидным внутренним фораменом. Спинная створка имеет мелкий широкий синус и низкую анаклинную ложную арею с небольшой вогнутой срединной пластиной, 